\title{
The contribution of the European Court of Human Rights to contemporary religious-related dilemmas
}

There have been an increasing number of applications before the European Court of Human Rights concerning religious diversity, indicating the growing importance of this topic in the European arena. Often criticised for being arbitrary and unpredictable, Roberta MeddaWindischer argues that the Courts approach to religion is pragmatic, but it must strengthen the role of the state as a promoter of tolerance.

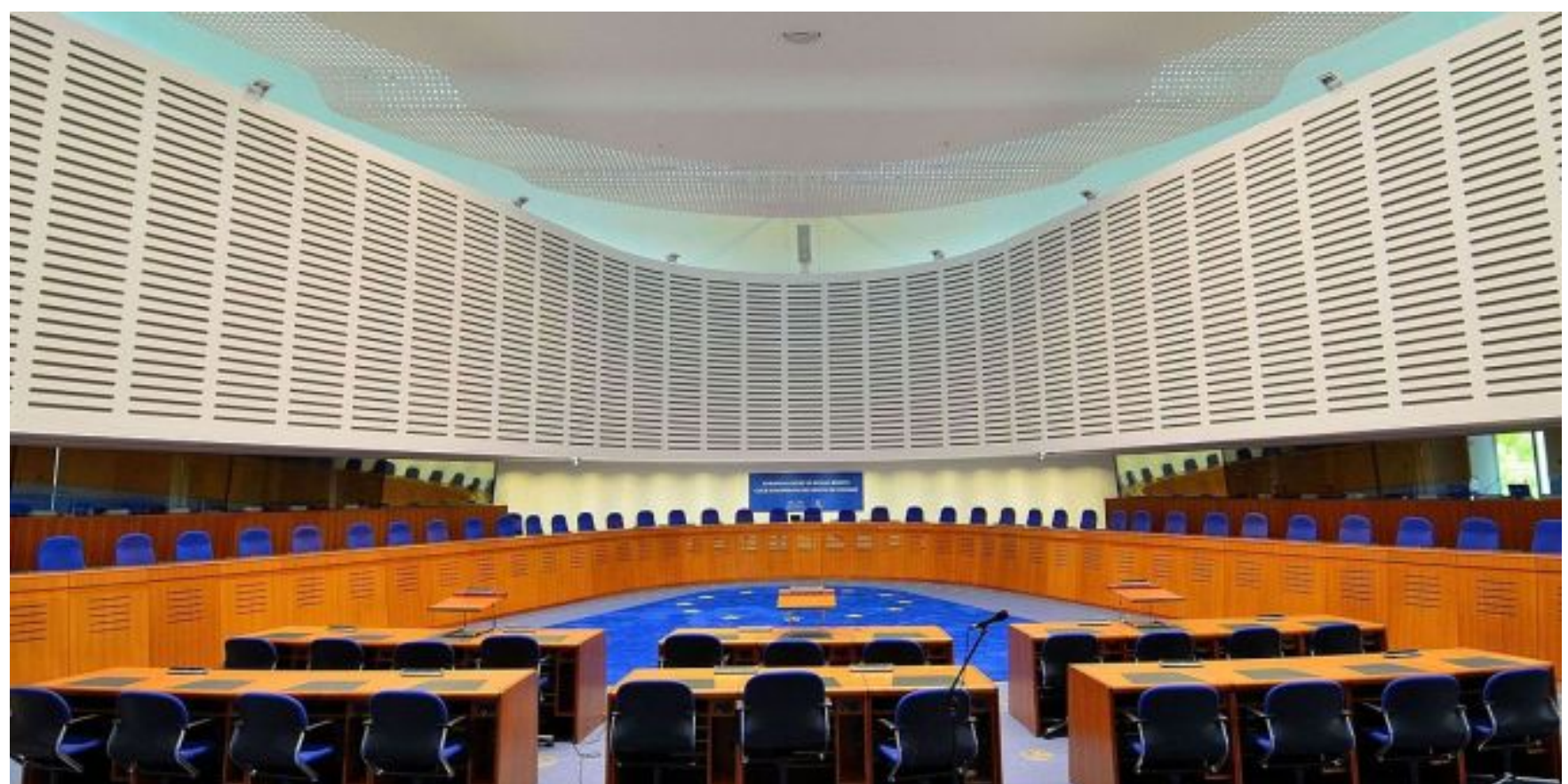

Courtroom of the European Court of Human Rights in Strasbourg. Creative Commons: Adrian Grycuk

The increased diversity of contemporary societies has multiplied the claims to accommodate diversity, in particular religious diversity, in different contexts of everyday life such as work places, schools, and public offices. Many of these issues and accommodation claims are brought up to the Strasbourg-based European Court of Human Rights, in charge of supervising the implementation of the European Convention on Human Rights. The Court has a rather broad jurisdiction covering not only all EU Member States -as the Luxembourg-based European Court of Justice- but also non-EU countries such as Turkey, Russia and Switzerland.

One of the main rules developed by the Strasbourg Court when deciding over cases regarding the right to freedom of thought, conscience, and religion, is that the right to manifest religion is not unconditional and this makes regulation and restrictions on this right possible. This is due to the fact that the Court interprets the right to freedom of religion as having two dimensions: internal and external. The internal freedom can only be unconditional because it concerns deep-seated ideas and convictions formed in an individual's conscience which cannot, in themselves, disturb public order and consequently cannot be limited by state authorities. In contrast, external freedom, despite its considerable importance, can only be relative. This relativity is logical inasmuch as, because the freedom in question is the freedom to manifest one's beliefs, public order or the rights of others, for instance, may be affected or even threatened. Consequently, although the freedom to hold beliefs and convictions can only be unconditional, the freedom to manifest them can be relative. 
The second important rule established by the European Court of Human Rights when deciding on cases related to freedom of religion, is that when regulating matters related to intimate personal convictions in the sphere of morals or religion, the Strasbourg Court has traditionally made available to the states a broad margin of appreciation because the Court sees this as an area in which there is considerable variation in practice due to the fact that even in a relative small continent as Europe it is not possible to discern a uniform conception of the significance of religion in society, and where even in a single country such conceptions may vary. Therefore, what is likely, for instance, to cause substantial offence to persons of a particular religion will vary significantly from time to time and from place to place, especially in an era characterised by an ever growing array of faiths and denominations.

The Strasbourg Court has thus taken the line that by reason of their direct and continuous contact with the vital forces of their countries, state authorities, including the national courts, are in principle in a better position than the international judge to give an opinion on the exact content and on the necessity of these restrictions, leaving to the international courts the competence to provide general guidelines and a framework of reference.

Obviously, this does not give the state an unlimited discretion to determine whether a restriction is proportionate to the aim pursued. In fact, if it is true that the Court leaves a certain amount of discretion for the states to decide whether a given course of action is compatible with the Convention requirements, it does reserve for itself the authority to review state actions against principles and limits set forth under the restriction invoked. Moreover, it is always open to the Court to narrow that margin should a more general consensus on the relationship between the state and the manifestation of religion or belief emerge. It follows from this that different responses to similar situations will be acceptable within the Convention framework, providing that they properly reflect a balancing of the particular issues in the contexts in which they emerge.

This means that the decisions of the Court in relation to freedom of religion must be treated with extreme caution: for example, just because a restriction on the wearing of a religious symbol has been upheld in one case does not mean that a similar restriction will be upheld in another, where the context may be very different. The risk with this approach is that the role of the Court is sometimes perceived as casuistic, arbitrary and unpredictable and that the Court is abdicating its role as authoritative standard setter in Europe and law harmonizer.

The interpretative rules seen above -legitimacy to impose restrictions on the right to manifest one's religion and the state's margin of appreciation- have been applied in several case related to freedom of religion, especially in cases on the use of religious symbols. In light of some recent cases, particularly those related to France and Turkey, on the bans on the use of burqa and niqab in public places and the use of the veil in public schools and universities (S.A.S. v. France, 2014; Şahin v. Turkey, 2005; Dahlab v. Switzerland, 2001) some consider that the Court has more frequently sustained a form of strict secularism, or even a sort of intolerant secularism or enlightenment fundamentalism. This is especially so in cases when individual religious manifestations do not display any signs of political intentions but are performed bona fide making these prohibitions difficult to reconcile with the necessity to protect a democratic society.

However, if it is true that the Strasbourg Court has in those cases displayed a rather restrictive approach to accommodate religious diversity, it is also true that in many other cases, the Court has discarded a militant form of secularism and has followed a more neutral approach, or in other terms, a pluralist, soft or open secularism model (Folgerø v. Norway, 2007; Lautsi v. Italy, 2011; Ewaida and others v. UK, 2013).

An additional principle applied by the Strasbourg Court particularly in cases related to morals and religion, is based on the assumption that the European Convention on Human Rights is a 'living instrument' which is to be interpreted in the light of present-day conditions. This means that the Strasbourg Court can be influenced by the developments of standards shared by its Contracting States and that the Court is able to address newly emerging issues or reconsider its own previous approaches and line of interpretation. In other words, the interpretative and imple $\wedge$ ing 
approaches set out in the Court's jurisprudence are not rigid and immutable but are open to reappraisal and adaptations to new standards, should they emerge among the contracting states of the Convention.

The principles applied so far by the Court in cases related to freedom of religion represent a pragmatic response to the variations existing among states in interpreting the right to manifest one's religion. In particular, the most controversial state's "margin of appreciation" can be considered as an implementation of the general principle of subsidiarity regulating - in international law - the relations between sovra-national and national bodies. However, this approach is only legitimate as long as, at the same time, the Court strengthens the proactive role of the state as mediator and promoter of tolerance among groups of believers and/or nonbelievers. The role of mediation performed by the state authorities, with the support of the Strasbourg Court, would be clearly beneficial for democratic societies as a whole as it will give opportunities for positive dialogue and a furthering of mutual respect and understanding which is so desperately needed in our contemporary, increasingly diversified societies.

This article is based on Roberta Medda-Windischer's article 'The Contribution of the European Court of Human Rights to Contemporary Religious-Related Dilemmas', European Yearbook of Minority Issues.

\section{About the author}

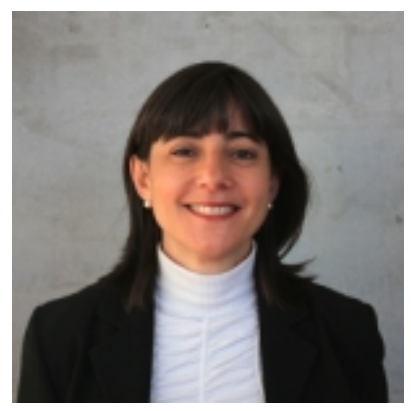

Dr. Roberta Medda-Windischer is Research Group Leader/Senior Researcher at the European Academy of Bolzano/Bozen (Eurac), Institute for Minority Rights. She has worked at the European Court of Human Rights. 